\title{
CONFIGURATION OF BURROW SITES OF YELLOW-NECKED FIELD MOUSE (Apodemus flavicollis argyropuli) IN FIELD CROP BIOTOPES IN IRAQI- KURDISTAN
}

\author{
Amin Abdo Khedher \\ Department of Forestry, College of Agriculture, University of Dohuk, Iraqi-Kurdistan
}

\begin{abstract}
AMIN A. KHEDHER.: CONFIGURATION OF BURROW SITES OF YELLOW-NECKED FIELD MOUSE (Apodemus flavicollis argyropuli) IN FIELD CROP BIOTOPES IN IRAQI-KURDISTAN. Hungarian Small Game Bulletin 12: 373-382. http://dx.doi.org/10.17243/mavk.2014.373

The aim of this study was to determine the relationship between the configuration of burrow sites with some edaphic factors and the plane shape of the tunnels. Divergent and straight lines digging direction were found in studied areas. Oblong and triangle plane shape were distinguished. The results has cleared that configuration of burrow sites has bigger influence on the plane shape of the tunnels than the other studied features. On the other hand, burrows were found only on the transition, upper slope and lower slope sites; while they were completely missing on the upper and lower plane sites. We found that digging system of burrows follows the shape of main cracks. The study showed that general slope $\%$ and direction of digging had no effect on plane shape. In addition, soil texture, especially the co-existence of silt with clay, played a higher role than the studied edaphic factors.
\end{abstract}

KEY WORDS: yellow-necked field mouse, tunnels, soil, topography

\section{INTRODUCTION}

Yellow-necked field mouse (Apodemus flavicollis argyropuli Ellerman and Morison Scott, 1951) is one of the biotic factors of agrobiotopes, which accomplish the agrobiocenosis (Hatt, 1959).

Biotic and abiotic ecological factors have certain interrelationships, which connect them with each other. In addition, there are biocenosis connections where the agro-ecosystem controls and regulates their activities and interactions (CORBET \& HILL, 1991; KADIM, 1994; BuCKLE \& SMITH, 1996; BOLEN \& RoBINSON, 2003). Each biotope has its own biocenosis, which cannot be isolated from it. Each biocenosis will differ from the other in their numbers and types according to their habitats. Connections between fossorial animals and their habitats are based on their life requirements, type of biological activities, species behavior and genetic factors as well (PETZSH, 1973; KOZAKIEWICZ, 1976; JOLSVAY et al., 1977).

Intraspecific interactions as mating, littering, as well as they find a good shelter for concealing from their enemies underground in their wavy tunnels (interspecific interactions) have a great importance (MONTGOMERY, 1979). Consequently, the animal has to dig down into the soil to make underground passages to achieve its requirements safely (TOMAN et al., 1981). Tunnel digging system depends upon the following points: (i) effectiveness of digging tool (the paws); (ii) soil type and its chemical and physical properties; (iii) instinctive behavior of burrowing animal, and how to search loose horizons in the soil. 
Abiotic factors, especially climatic factors such as temperature, light, wind, and humidity, play a large role in building up tunnel system. Cracks, which appears as a result of drought, expose the inner sides of soil profile to the sun and air causing deeper and wider cracks, so with the help of different types of erosion the cracks are filled with organic matter and topsoil, which has already high organic matter content. Furthermore, anthropogen activity plays a large role in filling the cracks. The operation will change some soil features, looses it and make it easily to dig. The burrowing animal will follow the loose horizons of a soil for making his tunnels (TOHME \& TOHME, 1985). Digging performance of an animal depends upon soil properties and animal digging ability and activity (SZÉKY, 1983).

Their damages and co-existence with other species in agricultural biotopes were the motivation of this study. The aim of the study was to find the relationship between burrow site configuration and the plane shape of the tunnels. Further goal was to find relationship between certain soil properties (type of soil, $\mathrm{CaCO} 3 \%$, organic matter $\%$, bulk density g/am ${ }^{3}$, particle density $\mathrm{g} / \mathrm{cm}^{3}$, porosity $\%$, slope $\%$ ) and the plane shape of the tunnels.

\section{MATERIALS AND METHOD}

\subsection{Study area}

Five regions of agricultural biotopes were selected namely Sumail, Girshin, Faishkhabour, Engineering college fields and Shawis.

\subsection{Field survey}

\section{Selection of burrows}

A donum with a high animal population was choosed within a hectare of each region. Random selection of five active burrows were taken place within a selected donum.

\section{Collection of data}

After fixing the site of the burrows, descriptive features of the soil surface around the burrows were determined, especially the configuration of the land (JALIL, 1987).

Five categories were established for the configuration of the land within selected biotopes (Fig. 1):

$a$ - upper plane site

$b$ - transition site

$c$ - upper slope site

$d$ - lower slope site

$e$ - lower plane site

Land slope was determined between selected burrows. Subsoil structure of the tunnels were also determined. Tunnel digging systems were focused concretely, on which sketches were made (Table 2). The plane shape of all tunnels for each burrow registered on a sheet, which was supposed according to tunnel digging system as: $a$ - oblong and $b$-triangle. 


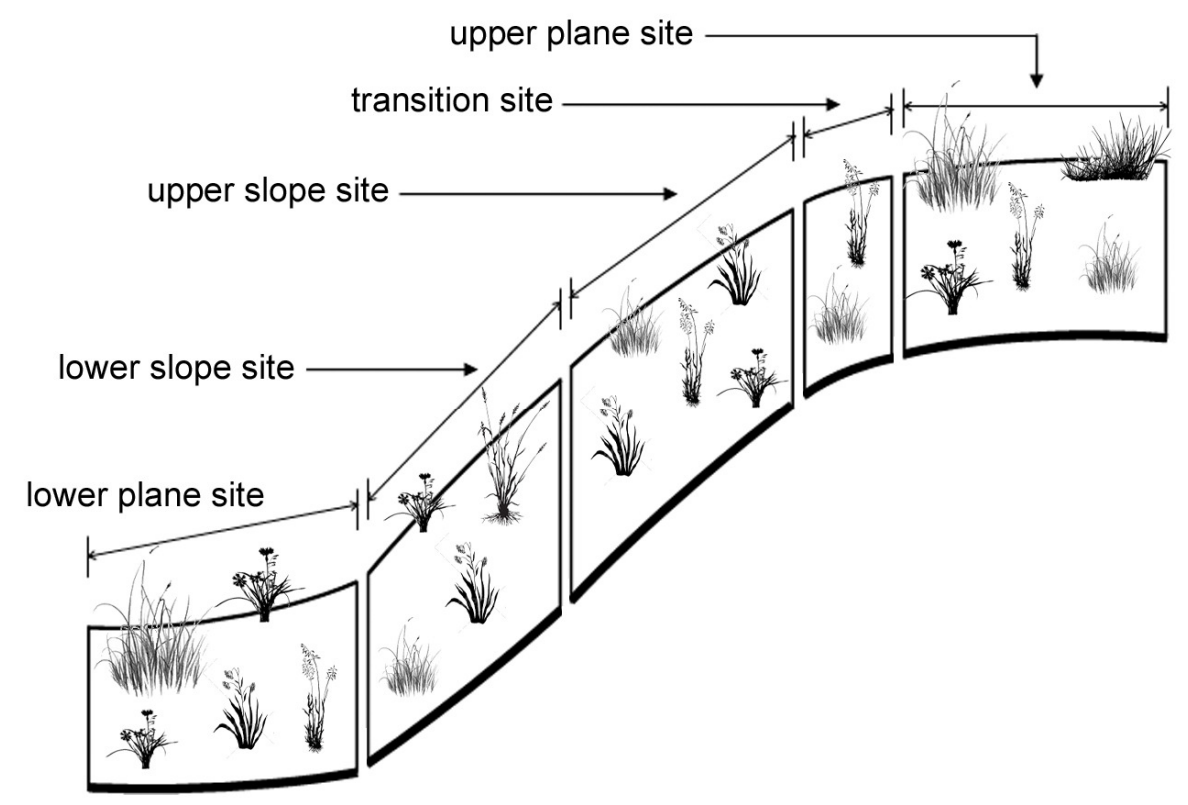

Figure 1: Configuration categories of burrow sites

\subsection{Data analysis}

We focused on the plane shape of tunnels as dependent variable, and other soil characteristics (organic matter $\%, \mathrm{CaCO}_{3} \%$, bulk density g/ $\mathrm{m}^{3}$, particle density g/am ${ }^{3}$, porosity $\%$, type of soil, slope $\%$ and the direction of digging tunnels) as independent variables. Analysis of variance and Duncan Multiple Range Test were used to show the effect of direction and location on the frequency of tunnel direction.

From a statistical point of view we used plane shape of digging system as dependent variable, which was assumed as qualitative or dummy variable. The qualitative variable indicates the presence or absence of the attribute. So to quantify the identified attribute, we had to give values of (1) and (0), where (0) indicates the absence while (1) indicates the presence of an attribute. Sketches and tables were also used in order to extract some relationship (Table 3).

\section{RESULTS AND DISCUSSION}

Burrows were found only on the transition, the upper slope and the lower slope lower. On the other hand, they were completely missing on the upper and lower plane sites, because of the absence of essential cracks. The digging system of burrows follows the shape of main cracks, especially in dry season, because of the external effects on the features of crack inner soil, which were caused by wind and water erosion, movements of animals or anthropogenic activities. These activities bring light organic matter and topsoil from surrounding areas to the cracks, which will be mixed with the inner soil. This phenomenon will change soil features in a way that makes easier for burrowing animals to dig. 
All the burrows on the transition site had a plane shape of oblong because the cracks here move in a parallel way with the line of the transition site.

In the upper slope and lower slope sites the cracks were branched in different ways, and the digging system always took an inclined shape (y) in the upper slope sites and vertical (Y) in the lower slope sites, which makes the plane shape to be a triangle (Fig. 2).

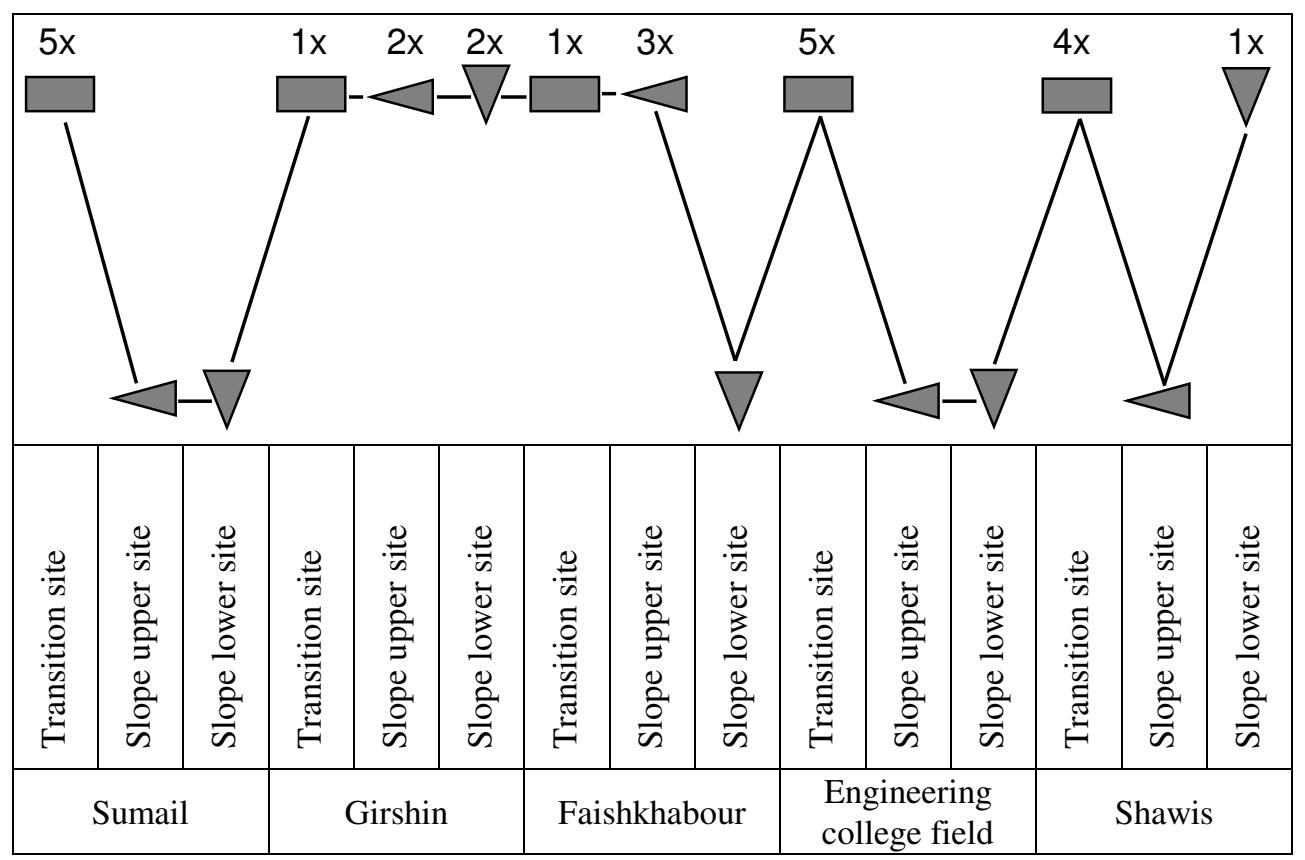

Figure 2: Plane shape and frequency of burrows on different soil surfaces within studied specimens

shape of burrows in transition site; $\square$ shape of burrows slope upper site; $\nabla$ shape of burrows in slope lower site; $\mathrm{nX}$ - frequency of burrows

In Sumail region all plane shapes were oblong because of their existence parallel with (BRC) fence located between field crops and vegetables and forms longitudinal cracks in dry seasons and makes the digging system to take a shape of oblong, Table 1 shows that Sumail, engineering fields and Shawis are dominated with oblong plane shape, while Girshin and Faishkhabour are dominated by burrows of triangle plane shape.

Digging direction lines were straight or divergent, some of them were refracted, branched, zigzagged or curved to different directions (N, NE, NW, E, W, S, SE and SW), Table 2.

Presence and absence of oblong or triangle plane shapes are well obvious in Table 3 and Fig. 2. $68 \%$ of burrows were found on transition sites, $20 \%$ on upper slope site and $12 \%$ on lower slope sites. 
Table 1: Plane shapes of tunnel systems against slope, soil texture and other soil properties for studied burrows

\begin{tabular}{|c|c|c|c|c|c|c|c|c|c|}
\hline \multirow{2}{*}{ Regions } & \multirow{2}{*}{$\begin{array}{c}\text { Burrow } \\
\text { No. }\end{array}$} & \multirow{2}{*}{ Soil texture } & \multirow{2}{*}{$\begin{array}{l}\text { Plane } \\
\text { shpe of } \\
\text { overall } \\
\text { tunnels }\end{array}$} & \multirow{2}{*}{$\underset{\%}{\text { Slope }}$} & \multicolumn{5}{|c|}{ Soil properties } \\
\hline & & & & & Organic matter \% & $\mathrm{CaCO}_{3} \%$ & Bulk density $\mathrm{g} / \mathrm{cm}^{3}$ & Particle density $\mathrm{g} / \mathrm{cm}^{3}$ & Porisity \% \\
\hline \multirow{5}{*}{ Sumail } & $\mathrm{I}$. & Clay loamy & Ob. & 40 & 2.77 & 19.5 & 1.4 & 2.5 & 44.0 \\
\hline & II. & Silty clay loamy & $\mathrm{Ob}$. & 35 & 3.50 & 17.5 & 1.2 & 2.6 & 53.8 \\
\hline & III. & Silty clay & $\mathrm{Ob}$. & 22 & 2.64 & 17.0 & 1.3 & 2.6 & 50.0 \\
\hline & IV. & Clay silty & $\mathrm{Ob}$. & 26 & 2.87 & 17.5 & 1.4 & 2.5 & 44.0 \\
\hline & $\mathrm{V}$. & Clay & $\mathrm{Ob}$. & 15 & 3.02 & 18.5 & 1.4 & 2.4 & 41.6 \\
\hline \multirow{5}{*}{ Girshin } & I. & Clay & $\mathrm{Ob}$. & 35 & 2.52 & 32.0 & 1.6 & 2.4 & 33.3 \\
\hline & II. & Clay & Tr. & 25 & 3.21 & 30.0 & 1.4 & 2.5 & 44.0 \\
\hline & III. & Clay & Tr. & 31 & 3.55 & 29.0 & 1.6 & 2.5 & 36.0 \\
\hline & IV. & Clay loamy & Tr. & 31 & 3.86 & 28.5 & 1.6 & 2.5 & 36.0 \\
\hline & $\mathrm{V}$. & Clay & Tr. & 15 & 3.51 & 28.5 & 1.5 & 2.6 & 42.3 \\
\hline \multirow{5}{*}{ Faishkhabour } & I. & Sandy clay loamy & $\mathrm{Ob}$. & 35 & 0.81 & 28.0 & 1.5 & 2.6 & 42.3 \\
\hline & II. & Sandy clay loamy & $\mathrm{Ob}$. & 38 & 0.89 & 29.0 & 1.6 & 2.6 & 38.4 \\
\hline & III. & Sandy loamy & Tr. & 30 & 0.93 & 28.0 & 1.4 & 2.6 & 46.1 \\
\hline & IV. & Sandy clay & Tr. & 45 & 1.30 & 27.0 & 1.6 & 2.5 & 36.0 \\
\hline & $\mathrm{V}$. & Sandy loamy & Tr. & 50 & 0.81 & 27.5 & 1.0 & 2.6 & 46.0 \\
\hline \multirow{5}{*}{$\begin{array}{l}\text { Engineering } \\
\text { college fields }\end{array}$} & I. & Clay loamy & $\mathrm{Ob}$. & 24 & 2.34 & 38.5 & 1.4 & 2.6 & 46.1 \\
\hline & II. & Silty clay & $\mathrm{Ob}$. & 23 & 2.88 & 38.5 & 1.5 & 2.6 & 42.3 \\
\hline & III. & Silty clay & $\mathrm{Ob}$. & 32 & 3.01 & 37.5 & 1.6 & 2.6 & 38.4 \\
\hline & IV. & Silty clay & $\mathrm{Ob}$. & 22 & 2.36 & 37.5 & 1.3 & 2.5 & 48.0 \\
\hline & $\mathrm{V}$. & Clay silty & $\mathrm{Ob}$. & 45 & 2.88 & 37.0 & 1.3 & 2.6 & 50.0 \\
\hline \multirow{5}{*}{ Shawis } & I. & Clay & $\mathrm{Ob}$. & 34 & 3.63 & 34.0 & 1.4 & 2.5 & 44.0 \\
\hline & II. & Clay & $\mathrm{Ob}$. & 25 & 2.19 & 35.0 & 1.4 & 2.5 & 44.0 \\
\hline & III. & Clay & $\mathrm{Ob}$. & 47 & 1.77 & 34.5 & 1.6 & 2.5 & 36.0 \\
\hline & IV. & Clay & $\mathrm{Ob}$. & 43 & 2.58 & 33.5 & 1.5 & 2.5 & 40.0 \\
\hline & V. & Clay & Tr. & 30 & 2.14 & 36.0 & 1.5 & 2.6 & 42.3 \\
\hline
\end{tabular}

Ob. - oblong; Tr. - triangle 
Table 2: Plane shapes of tunnel systems against digging direction of tunnels

\begin{tabular}{|c|c|c|c|}
\hline Studied regions & $\begin{array}{l}\text { Burrow } \\
\quad \text { No. }\end{array}$ & Description of digging direction & $\begin{array}{l}\text { Plane shape of } \\
\text { digging system }\end{array}$ \\
\hline \multirow{5}{*}{ Sumail } & I. & - Divergent lines to NE. almost E. and SE. almost E. & $\mathrm{Ob}$ \\
\hline & II. & - Straight line to NE. then curved to SE. & $\mathrm{Ob}$. \\
\hline & III. & - Straight line to SE., almost E. & $\mathrm{Ob}$. \\
\hline & IV. & $\begin{array}{l}\text { - Straight line to NE., almost E., refracted suddenly to } \\
\text { SE., almost S. }\end{array}$ & $\mathrm{Ob}$ \\
\hline & $\mathrm{V}$. & - Straight line to NE., almost E. & $\mathrm{Ob}$. \\
\hline \multirow{5}{*}{ Girshin } & I. & $\begin{array}{l}\text { - Straight line to E., refracted with an obtuse angle to } \\
\text { NW. }\end{array}$ & $\mathrm{Ob}$ \\
\hline & II. & - Straight line to SE., sharply refracted to NE. & Tr. \\
\hline & III. & - Divergent lines to W. and N. & Tr. \\
\hline & IV. & - Straight line to E., then branched to NE. and SE. & Tr. \\
\hline & $\mathrm{V}$. & - Straight line to E., then branched to NE. and SE. & Tr. \\
\hline \multirow{5}{*}{ Faishkhabour } & I. & $\begin{array}{l}\text { - Straight line to NE., almost N., then branched to } \\
\text { NW. and SW. }\end{array}$ & $\mathrm{Ob}$ \\
\hline & II. & - Straight line to NW. zigzags to SW., then to NW. & $\mathrm{Ob}$. \\
\hline & III. & - Straight line to SW. branched to W. & Tr. \\
\hline & IV. & $\begin{array}{l}\text { - Straight line to NW. branched to NW. and SW., } \\
\text { then zigzags to NW. and ended with W. }\end{array}$ & $\operatorname{Tr}$. \\
\hline & V. & $\begin{array}{l}\text { - Straight line to W. sharply refracted to SW., ended } \\
\text { to two branches. }\end{array}$ & Tr. \\
\hline \multirow{5}{*}{$\begin{array}{l}\text { Engineering college } \\
\text { fields }\end{array}$} & I. & - Divergent lines to opposite directions NE. and SE. & $\mathrm{Ob}$. \\
\hline & II. & - Divergent lines to SW. and NW. & $\mathrm{Ob}$. \\
\hline & III. & - Divergent lines to NW. and NE. & Ob. \\
\hline & IV. & - Divergent lines to S. and W. & $\mathrm{Ob}$. \\
\hline & $\mathrm{V}$. & - Divergent lines to NE. and NW. & Ob. \\
\hline \multirow{5}{*}{ Shawis } & I. & - Straight line to NW. & Ob. \\
\hline & II. & $\begin{array}{l}\text { - Divergent lines to SE. and NW., refracted to NW. } \\
\text { too and ended with two branches. }\end{array}$ & $\mathrm{Ob}$ \\
\hline & III. & - Straight line to NE. & $\mathrm{Ob}$. \\
\hline & IV. & $\begin{array}{l}\text { - Divergent lines to SE., curved rightly to NE. and } \\
\text { refracted to NW., but on other side takes SW. } \\
\text { direction. }\end{array}$ & $\mathrm{Ob}$ \\
\hline & V. & - Divergent lines to SW. almost S. and NW. & Tr. \\
\hline
\end{tabular}

Abbr.: Ob. - oblong; Tr. - triangle

By observing the results of studied features in Table 1 and rearranging them upwards in Table 4, we can see that in Sumail and Engineering college fields the plane shape was not affected by increasing or decreasing values of organic matter, $\mathrm{CaCO} 3$, bulk density, particle density and porosity, which could be attributed to the looseness and soil water content, while in other regions (Girshin, Faishkhabour and Shawis) we experienced different pattern. 
Table 3: Presence-absence of burrows in the different sites

\begin{tabular}{|c|c|c|c|c|c|c|c|c|c|c|c|c|c|c|c|}
\hline Regions of study & \multicolumn{3}{|c|}{ Sumail } & \multicolumn{3}{|c|}{ Girshin } & \multicolumn{3}{|c|}{ Faishkhabour } & \multicolumn{3}{|c|}{$\begin{array}{l}\text { Engineering } \\
\text { college field }\end{array}$} & \multicolumn{3}{|c|}{ Shawis } \\
\hline $\begin{array}{l}\text { Site of digging } \\
\text { burrows }\end{array}$ & 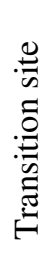 & 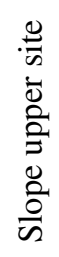 & 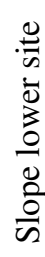 & 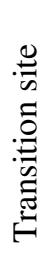 & 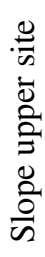 & 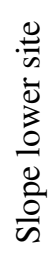 & 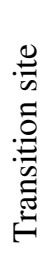 & 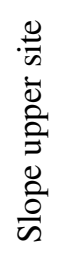 & 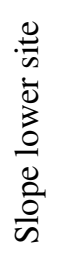 & 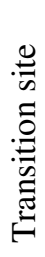 & 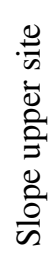 & 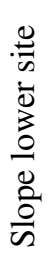 & 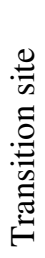 & 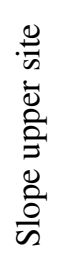 & 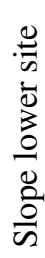 \\
\hline Burrow No. I. & 1 & 0 & 0 & 1 & 0 & 0 & 1 & 0 & 0 & 1 & 0 & 0 & 1 & 0 & 0 \\
\hline Burrow No. II. & 1 & 0 & 0 & 0 & 0 & 1 & 1 & 0 & 0 & 1 & 0 & 0 & 1 & 0 & 0 \\
\hline Burrow No. III. & 1 & 0 & 0 & 0 & 1 & 0 & 0 & 1 & 0 & 1 & 0 & 0 & 1 & 0 & 0 \\
\hline Burrow No. IV. & 1 & 0 & 0 & 0 & 0 & 1 & 0 & 1 & 0 & 1 & 0 & 0 & 1 & 0 & 0 \\
\hline Burrow No. V. & 1 & 0 & 0 & 0 & 1 & 0 & 0 & 1 & 0 & 1 & 0 & 0 & 0 & 0 & 1 \\
\hline
\end{tabular}

Table 4: Re-arranging the values of studied features upwards against the plane shapes of tunnel systems for studied areas.

\begin{tabular}{|c|c|c|c|c|c|}
\hline Regions of study & Sumail & Girshin & Faishkhabour & $\begin{array}{c}\text { Engineeing } \\
\text { college fields }\end{array}$ & Shawis \\
\hline \multirow[t]{5}{*}{ Organic matter $\%$} & $3.50 \mathrm{ob}$. & $3.86 \mathrm{Tr}$. & $1.30 \mathrm{Tr}$. & $3.01 \mathrm{Ob}$ & $3.63 \mathrm{Ob}$. \\
\hline & $3.02 \mathrm{Ob}$. & $3.55 \mathrm{Tr}$. & $0.93 \mathrm{Tr}$. & $2.88 \mathrm{Ob}$. & $2.58 \mathrm{Ob}$. \\
\hline & $2.87 \mathrm{Ob}$. & $3.51 \mathrm{Tr}$. & $0.89 \mathrm{Ob}$. & $2.88 \mathrm{Ob}$ & $2.19 \mathrm{Ob}$. \\
\hline & $2.77 \mathrm{Ob}$. & $3.21 \mathrm{Tr}$. & $0.81 \mathrm{Ob}$. & $2.36 \mathrm{Ob}$ & 2.14 Tr. \\
\hline & $2.64 \mathrm{Ob}$. & $2.52 \mathrm{Ob}$. & $0.81 \mathrm{Tr}$. & $2.34 \mathrm{Ob}$. & $1.77 \mathrm{Ob}$. \\
\hline \multirow{5}{*}{$\mathrm{CaCO} 3 \%$} & $19.5 \mathrm{Ob}$. & $32.0 \mathrm{Ob}$. & $29.0 \mathrm{Ob}$. & $38.5 \mathrm{Ob}$. & $36.0 \mathrm{Tr}$. \\
\hline & $18.5 \mathrm{Ob}$. & $30.0 \mathrm{Tr}$. & $28.0 \mathrm{Ob}$. & $38.5 \mathrm{Ob}$. & $35.0 \mathrm{Ob}$. \\
\hline & $17.5 \mathrm{Ob}$. & $29.0 \mathrm{Tr}$. & $28.0 \mathrm{Tr}$. & $37.5 \mathrm{Ob}$. & $34.5 \mathrm{Ob}$. \\
\hline & $17.5 \mathrm{Ob}$. & $28.5 \mathrm{Tr}$. & $27.5 \mathrm{Tr}$. & $37.5 \mathrm{Ob}$. & $34.0 \mathrm{Ob}$. \\
\hline & 17.0 Ob. & $28.5 \mathrm{Tr}$. & $27.0 \mathrm{Tr}$. & 37.0 Ob. & 33.5 Ob. \\
\hline \multirow{5}{*}{ Bulk density $\mathrm{g} / \mathrm{cm}^{3}$} & $1.4 \mathrm{Ob}$. & $1.6 \mathrm{Ob}$. & $1.6 \mathrm{Ob}$. & $1.6 \mathrm{Ob}$. & $1.6 \mathrm{Ob}$. \\
\hline & $1.4 \mathrm{Ob}$. & $1.6 \mathrm{Tr}$. & $1.6 \mathrm{Tr}$. & $1.5 \mathrm{Ob}$. & $1.5 \mathrm{Tr}$. \\
\hline & $1.4 \mathrm{Ob}$. & $1.6 \mathrm{Tr}$. & $1.5 \mathrm{Ob}$. & $1.4 \mathrm{Ob}$. & $1.5 \mathrm{Ob}$. \\
\hline & $1.3 \mathrm{Ob}$ & $1.5 \mathrm{Tr}$. & $1.4 \mathrm{Tr}$. & $1.3 \mathrm{Ob}$ & $1.4 \mathrm{Ob}$. \\
\hline & $1.2 \mathrm{Ob}$ & $1.4 \mathrm{Tr}$. & $1.0 \mathrm{Tr}$. & $1.3 \mathrm{Ob}$. & $1.4 \mathrm{Ob}$. \\
\hline \multirow{5}{*}{ Particle density $\mathrm{g} / \mathrm{cm}^{3}$} & $2.6 \mathrm{Ob}$ & $2.6 \mathrm{Tr}$. & $2.6 \mathrm{Ob}$ & $2.6 \mathrm{Ob}$ & $2.6 \mathrm{Tr}$. \\
\hline & $2.6 \mathrm{Ob}$. & $2.5 \mathrm{Tr}$. & $2.6 \mathrm{Ob}$. & $2.6 \mathrm{Ob}$. & $2.5 \mathrm{Ob}$. \\
\hline & $2.5 \mathrm{Ob}$ & $2.5 \mathrm{Tr}$. & $2.6 \mathrm{Tr}$. & $2.6 \mathrm{Ob}$ & $2.5 \mathrm{Ob}$ \\
\hline & $2.5 \mathrm{Ob}$ & $2.5 \mathrm{Tr}$. & $2.6 \mathrm{Tr}$. & $2.6 \mathrm{Ob}$. & $2.5 \mathrm{Ob}$ \\
\hline & $2.4 \mathrm{Ob}$. & $2.4 \mathrm{Ob}$. & $2.5 \mathrm{Tr}$. & $2.5 \mathrm{Ob}$ & $2.5 \mathrm{Ob}$ \\
\hline \multirow{5}{*}{ Porisity \% } & $53.8 \mathrm{Ob}$. & $44.0 \mathrm{Tr}$. & $46.1 \mathrm{Tr}$. & $50.0 \mathrm{Ob}$. & $44.0 \mathrm{Ob}$. \\
\hline & $50.0 \mathrm{Ob}$. & 42.3 Tr. & $46.1 \mathrm{Tr}$. & $48.0 \mathrm{Ob}$ & $44.0 \mathrm{Ob}$. \\
\hline & $44.0 \mathrm{Ob}$. & $36.0 \mathrm{Tr}$. & $42.3 \mathrm{Ob}$. & $46.1 \mathrm{Ob}$. & 42.3 Tr. \\
\hline & $44.0 \mathrm{Ob}$. & $36.0 \mathrm{Tr}$. & $38.4 \mathrm{Ob}$. & $42.3 \mathrm{Ob}$. & $40.0 \mathrm{Ob}$. \\
\hline & $41.6 \mathrm{Ob}$. & $33.3 \mathrm{Ob}$. & $36.0 \mathrm{Tr}$. & $38.4 \mathrm{Ob}$. & $36.0 \mathrm{Ob}$. \\
\hline
\end{tabular}

Abbr. Ob. - oblong; Tr. - triangle.

No relationship was found between the slope and plane shape, neither between the direction of digging and plane shape of tunnels. While soil texture showed different influences 
on the same site, a general conclsion cannot be drawn. Silty soils or soils in which silt plays an important role motive the soil to form row cracks as a result of drought and high temperature, which makes the tunnel system to take a shape of oblong and reduces the branching of tunnels.

Soil texture has therefore a big influence on forming a plane shape of tunnels, especially the presence of silt with clay (Table 5).

Table 5: The frequency of plane shape of tunnel systems for each type of soil in studied area

\begin{tabular}{|l|c|c|}
\hline \multirow{2}{*}{ Soil texture } & \multicolumn{2}{|c|}{ Plane shape } \\
\cline { 2 - 3 } & Oblong & Triangle \\
\hline 1- Clay & 6 & 4 \\
\hline 2- Clay leamy & 2 & 1 \\
\hline 3- Clay silty & 2 & - \\
\hline 1- Silty clay & 4 & - \\
\hline 2- silty clay loamy & 1 & - \\
\hline 1- Sandy loamy & - & 2 \\
\hline 2- sandy clay loamy & 2 & 1 \\
\hline
\end{tabular}

Table 6 shows the significance of directions, locations and the interaction between directions and locations.

Table 6: Analysis of variance, effect of the direction and location on direction frequency of tunnels

\begin{tabular}{|l|c|c|c|c|c|c|}
\hline S.O.V & D.F. & Anovass & Mean square & F cal. & F. Tab & Significance \\
\hline Directions & 7 & 27.7950 & 3.9707 & 11.19 & 0.0001 & $* *$ \\
\hline Locations & 4 & 4.3800 & 1.0950 & 3.08 & 0.0177 & $*$ \\
\hline Direction \& locations & 28 & 28.1800 & 1.0064 & 2.84 & 0.0001 & $* *$ \\
\hline
\end{tabular}

Number of observation $=200 ; * *$ significant at 0.01 probability level; $*$ significant at 0.05 probability level.

Table 7 shows Duncan's test for the effect of direction in all locations on the mean frequency of tunnel direction.

Table 7: Effect of direction on the mean frequency of tunnels direction (Duncan's test, all locations)

\begin{tabular}{|c|c|c|c|c|c|c|c|c|}
\hline \multirow{2}{*}{ Characters } & \multicolumn{8}{|c|}{ Direction } \\
\hline & NW & $\mathbf{N}$ & NE & $\mathbf{E}$ & SE & S & SW & W \\
\hline \multirow{2}{*}{ Frequency of tunnel direction } & 1.04 & 0.04 & 0.72 & 0.20 & 0.68 & 0.04 & 0.72 & 0.04 \\
\hline & $\mathrm{a}$ & $\mathrm{b}$ & $\mathrm{a}$ & $\mathrm{b}$ & $\mathrm{a}$ & $\mathrm{b}$ & $\mathrm{a}$ & B \\
\hline
\end{tabular}

Table 8 shows Duncan's test for the effect of all direction locations on the mean frequency of tunnel direction. There was no significant differences between Fasihkhabor and Engineering College Fields, also there was no significantly between Sumail, Girshin and Shawis locations, which can be explained by the soil texture. 
Table 8: Effect of location on mean frequency of tunnel directions (Duncan's test)

\begin{tabular}{|c|c|c|c|c|c|}
\hline \multirow{2}{*}{ Character } & \multicolumn{5}{|c|}{ Location } \\
\cline { 2 - 6 } & Sumail & Girshin & Faishkhabour & $\begin{array}{c}\text { Engineering } \\
\text { College Fields }\end{array}$ & Shawis \\
\hline Frequency of tunnel direction & $\begin{array}{c}0.375 \\
\mathrm{~b}\end{array}$ & $\begin{array}{c}0.40 \\
\mathrm{~b}\end{array}$ & $\begin{array}{c}0.45 \\
\mathrm{ab}\end{array}$ & $\begin{array}{c}0.70 \\
\mathrm{a}\end{array}$ & $\begin{array}{c}0.25 \\
\mathrm{~b}\end{array}$ \\
\hline
\end{tabular}

No significant differences were found between locations and main directions (N, E, S, $\mathrm{W}$ ), while secondary directions showed different relationships with the locations, which can be attributed to the effect of soil texture and soil water content (Table 9).

Table 9: Interaction effect of the direction and location on the mean frequency of tunnel directions

\begin{tabular}{|c|c|c|c|c|c|}
\hline \multirow[b]{2}{*}{ Directions } & \multicolumn{5}{|c|}{ Locations } \\
\hline & Sumail & Girshin & Faishkhabour & $\begin{array}{c}\text { Engineering } \\
\text { College Fields }\end{array}$ & Shawis \\
\hline NW & $\begin{array}{c}0.20 \\
\text { e.f }\end{array}$ & $\begin{array}{l}0.40 \\
\text { d.f }\end{array}$ & $\begin{array}{c}2.00 \\
\mathrm{a}\end{array}$ & $\begin{array}{c}1.80 \\
\text { a.b }\end{array}$ & $\begin{array}{l}0.80 \\
\text { c.f }\end{array}$ \\
\hline $\mathrm{N}$ & $\begin{array}{c}0.20 \\
\text { e.f }\end{array}$ & $\begin{array}{c}0.00 \\
\mathrm{f}\end{array}$ & $\begin{array}{c}0.00 \\
\mathrm{f}\end{array}$ & $\begin{array}{c}0.00 \\
\mathrm{f}\end{array}$ & $\begin{array}{c}0.00 \\
\mathrm{f}\end{array}$ \\
\hline $\mathrm{NE}$ & $\begin{array}{l}1.00 \\
\text { b.e }\end{array}$ & $\begin{array}{l}1.00 \\
\text { b.e }\end{array}$ & $\begin{array}{c}0.00 \\
\mathrm{f}\end{array}$ & $\begin{array}{c}1.40 \\
\text { a.c }\end{array}$ & $\begin{array}{c}0.20 \\
\text { e.f }\end{array}$ \\
\hline $\mathrm{E}$ & $\begin{array}{l}0.40 \\
\text { d.f }\end{array}$ & $\begin{array}{l}0.60 \\
\text { c.f }\end{array}$ & $\begin{array}{c}0.00 \\
\mathrm{f}\end{array}$ & $\begin{array}{c}0.00 \\
\mathrm{f}\end{array}$ & $\begin{array}{c}0.00 \\
\mathrm{f}\end{array}$ \\
\hline SE & $\begin{array}{l}1.20 \\
\text { a.d }\end{array}$ & $\begin{array}{l}0.40 \\
\text { d.f }\end{array}$ & $\begin{array}{l}0.20 \\
\text { e.f }\end{array}$ & $\begin{array}{l}1.00 \\
\text { b.e }\end{array}$ & $\begin{array}{l}0.60 \\
\text { c.f }\end{array}$ \\
\hline S & $\begin{array}{c}0.00 \\
\mathrm{f}\end{array}$ & $\begin{array}{c}0.20 \\
\text { e.f }\end{array}$ & $\begin{array}{c}0.00 \\
\mathrm{f}\end{array}$ & $\begin{array}{c}0.00 \\
\mathrm{f}\end{array}$ & $\begin{array}{c}0.00 \\
\mathrm{f}\end{array}$ \\
\hline SW & $\begin{array}{c}0.00 \\
\mathrm{f}\end{array}$ & $\begin{array}{l}0.60 \\
\text { c.f }\end{array}$ & $\begin{array}{l}1.40 \\
\text { a.c }\end{array}$ & $\begin{array}{l}1.20 \\
\text { a.d }\end{array}$ & $\begin{array}{l}0.40 \\
\text { d.f }\end{array}$ \\
\hline $\mathrm{W}$ & $\begin{array}{c}0.00 \\
\mathrm{f}\end{array}$ & $\begin{array}{c}0.00 \\
\mathrm{f}\end{array}$ & $\begin{array}{c}0.00 \\
\mathrm{f}\end{array}$ & $\begin{array}{l}0.20 \\
\text { e.f }\end{array}$ & $\begin{array}{c}0.00 \\
\mathrm{f}\end{array}$ \\
\hline
\end{tabular}

Averages with the same letter are not significantly different

\section{REFERENCES}

AlhuB, J.A. (1987): Agricultural Rodents, Their Damages and Control, General Body of Training and Agricultural Extension. Publishing Press, 31-32 (in Arabic).

BolEn E.G. \& RoBINSON W.L. (2003): Wildlife Ecology and Management. Fifth edition, Prentice Hall, Pearson Education, Inc. Upper Saddle River, New Jersey, 634 p.

BuCKLE A.P. \& SMITH R.H. (1996): Rodents Pests and their Control. CAB International. 45-47.

CORBET G.B. \& HILL, J.E. (1991): A world list of Mammalian species. British Museum (Natural History), London. 226 p.

HATT, R.T. (1959): The Mammals of Iraq. Miscellaneous publications, Museum of Zoology, University of Michigan, No. 106: 84-85.

Jolsvay A., SteinManN H. \& SzILY E. (1977): A magyar állatvilag szótára. Natura Kiadó, Budapest, $357 \mathrm{p}$.

KadiM, A.H. (1994): Controlling of Rodents, Science Encyclopedia 17, Freedom Publishing Press, 40-44. (in Arabic). 
KoZAKIEWICZ, M. (1976): Migratory Tendencies in Population of Bank Voles and Description of Migrants. Acta Theriologica 21: 321-338. http://dx.doi.org/10.4098/AT.arch.76-32

MONTGOMERY, W.I. (1979): An examination of interspecific, sexual and individual biases affecting rodent captures in Longworth traps. Acta Theriologica 24(3): 35-45. http://dx.doi.org/10.4098/AT.arch.79-4

PEARSON, B. \& BURTON, J.A. (1986): Emlös állatok. Gondolat Könyvkiadó, Budapest, 239 p.

Petzsch, H. (1973): Emlősök. Urania Állatvilag. Második Kiadás, Gondolat Kiadó, Budapest 173175.

SZÉKY P. (1983): Ökológia kislexikon. Natura Kiadó, Budapest 177 p.

Tohme, G. \& ToHME, H. (1985): Les Mammiferes sauvages du Liban. Publications de l'Université libanaise, Section des Sciences Naturelles 16. Beyrouth, Liban. 189 p.

TOMAn, J., FELIX, J. \& HISEK, K. (1981): A természet képekben. Natura Kiadó, Budapest, 430 p. 